\title{
Acute pulmonary toxoplasmosis with alveolitis of T suppressor lymphocyte type
}

\author{
O MICHEL, R SERGYSELS
}

From the Clinic of Respiratory Diseases, Saint-Pierre University Hospital, Brussels, Belgium

There are few reports of pulmonary manifestations of systemic toxoplasmosis in previously healthy people. ${ }^{12}$ We present the case history of a patient with clinical evidence of toxoplasma pneumonitis from whom bronchoalveolar lavage material was obtained before and after successful treatment.

\section{Case report}

A 21 year old Portuguese man became ill in November 1984 with high fever, dry cough, shivers, myalgia, arthralgia, and exanthema. He had no previous relevant medical history. He smoked 50 cigarettes a day and was an assistant cook.

On physical examination the patient was febrile $\left(39^{\circ} \mathrm{C}\right)$. Cervical lymphadenopathy, pharyngitis, bilateral crackles, hepatomegaly, and rash were present. The chest radiograph showed a bilateral interstitial infiltration. The relevant laboratory findings were: arterial blood gases- $\mathrm{pH} 7 \cdot 45$, $\mathrm{Po}_{2} 6.9 \mathrm{kPa}(52 \mathrm{~mm} \mathrm{Hg}), \mathrm{PCO}_{2} 4.3 \mathrm{kPa}(32 \mathrm{~mm} \mathrm{Hg})$; total leucocytes $7.4 \times 10^{9} / 1$ (neutrophils $81 \%$, lymphocytes $13 \%$, atypical lymphocytes $4 \%$, monocytes $1 \%$, eosinophils $1 \%$ ), platelets $70 \times 10^{9} / 1$; fibrinogenaemia $3.44 \mathrm{~g} / \mathrm{l}$; erythrocyte sedimentation rate $7 \mathrm{~mm}$ in one hour; glutamic oxaloacetic transaminase $63 \mathrm{IU} / 1$ (normal value <22 IU/1); glutamic pyruvate transaminase $35 \mathrm{IU} / 1 \quad(<20 \mathrm{IU} / \mathrm{l})$; lactate dehydrogenase $1084 \mathrm{IU} / 1$ ( < 195 IU/1); creatinine phosphokinase $243 \mathrm{IU} / \mathrm{l}(<110 \mathrm{IU} / \mathrm{l})$.

The delayed skin tests for tuberculin (5TU), streptokinase-streptodornase, and phytohaemagglutinin gave negative results. Respiratory function tests indicated a mild restrictive pattern, with vital capacity 3.821 ( $76 \%$ of predictive value), total lung capacity 5.091 ( $78 \%$ predicted), and impaired carbon monoxide gas transfer (TLCo

Address for reprint requests: $\operatorname{Dr} \mathrm{O}$ Michel, Voies respiratoires, Hôpital Universitaire Saint-Pierre, 1000 Bruxelles, Belgium.

Accepted 17 February 1986

Lymphocyte surface phenotypes
$16.66 \mathrm{ml} \mathrm{min}^{-1} \mathrm{~mm} \mathrm{Hg}, 49 \%$ predicted). Blood and sputum cultures were negative. Routine fibreoptic bronchoscopy was of no diagnostic value. Bronchoalveolar lavage fluid $\rightarrow$ (50 $\mathrm{ml}$ five times) contained an excess of lymphocytes $\overrightarrow{\mathrm{N}}$ (neutrophils $1 \%$, lymphocytes $22 \%$, macrophages $75 \%$, epithelial cells $1.6 \%$ ), some of which were seen to form rosettes $N$ around macrophages. The cell surface phenotype of bloodo and alveolar lymphocytes was determined (table) by a pre- viously described technique. ${ }^{3}$

The patient was treated from admission with erythro- $\mathbb{D}$ mycin $3 \mathrm{~g} /$ day. After 10 days the fever resolved and the chest $\overparen{\varnothing}$ radiograph and the arterial oxygen tension $\left(\mathrm{Po}_{2}\right)$ returned to normal. Erythromycin was discontinued and the patient $\subseteq$ remained afebrile. He was discharged on the 22 nd day. At $\overrightarrow{ }$ the time of discharge there was no serological evidence of $\vec{\infty}$ legionnaires' disease or of mycoplasma or virus disease and serological tests for HTLV-3 also gave a negative result. $\square$ Toxoplasma titres were, however, suggestive of an acute infection: from the first to the 10th day the Sabin Feldman titre increased from $1 / 1000$ to $1 / 4000$, the complement fixation titre from 0 to $1 / 64$, and the immunofluorescence $\frac{2}{D}$ titre for IgM from $1 / 320$ to $1 / 1280$.

The patient was therefore treated with sulphadiazine and $\overrightarrow{\overrightarrow{0}}$ pyrimethamine. After three months' treatment the 3 differential cell count of the lavage fluid had returned to normal (neutrophils 3\%, lymphocytes $1 \%$, macrophages $96 \%$ ). The relative and absolute numbers of $\mathrm{OKT}^{+}$and OKT $4^{+}$lymphocytes in the peripheral blood had also returned to normal. The percentage of $\mathrm{OKT}^{+}$cells remained high, although the absolute number fell within the normal range. The serological test for toxoplasma showed a 3 decrease in the complement fixation (1/32) and IgM. immunofluorescence (1/40) titres.

\section{Discussion}

In our patient systemic infection with toxoplasma is suggested by the clinical picture, ${ }^{4}$ and by the investigations,

\begin{tabular}{|c|c|c|c|c|}
\hline \multirow[b]{2}{*}{ Cell reactivity } & \multirow{2}{*}{$\begin{array}{l}7 \text { normal controls } \\
\left(\text { blood }^{*}\right)\end{array}$} & \multicolumn{2}{|c|}{ Before treatment } & \multirow{2}{*}{$\begin{array}{l}\text { After treatment } \\
\text { (blood) }\end{array}$} \\
\hline & & Blood & Alveolar & \\
\hline $\begin{array}{l}\text { OKT3 relative }(\% \text { lymphoid cells }) \\
\text { absolute (cells } / \mathrm{ml}) \\
\text { OKT4 relative }(\% \text { lymphoid cells) } \\
\text { absolute (cells } / \mathrm{ml}) \\
\text { OKT } 8 \text { relative }(\% \text { lymphoid cells }) \\
\text { absolute (cells } / \mathrm{ml}) \\
\text { OKT4:OKT8 ratio }\end{array}$ & $\begin{array}{l}51-86 \\
296-3760 \\
24-51 \\
160-1512 \\
4-24 \\
180-1268 \\
0 \cdot 57-1 \cdot 73\end{array}$ & $\begin{array}{r}89 \\
3973 \\
8 \\
357 \\
58 \\
2589 \\
0.14\end{array}$ & $\begin{array}{l}67 \\
9 \\
39 \\
0 \cdot 21\end{array}$ & $\begin{array}{r}81 \\
2138 \\
29 \\
765 \\
43 \\
1135 \\
0.67\end{array}$ \\
\hline
\end{tabular}


including the presence of atypical lymphocytes in the peripheral blood. The diagnosis was confirmed by finding a considerable rise in antibody titre in complement fixation, immunofluorescence, and Sabin-Feldman tests on paired sera. ${ }^{5}$ Pneumonitis was diagnosed from the clinical, radiological, and physiological features and bronchoalveolar lavage produced an abnormal number of lymphocytes.

In the few published reports pulmonary toxoplasmosis is always associated with systemic toxoplasmosis. ${ }^{12}$ It has been shown that infection with Toxoplasma gondii is followed by an increase in the peripheral blood of $0 \mathrm{OT} 8^{+}$ (suppressor) and $\mathrm{OKT}^{+}{ }^{+}$(total T cells) lymphocytes. ${ }^{67}$ This was confirmed in our patient. Similar changes in T lymphocytes subclasses may also be observed in other intracellular infections-for example, Epstein-Barr virus ${ }^{8}$ and cytomegalovirus. ${ }^{6}$ Quinnan et al ${ }^{9}$ have shown that the OKT8 subclass may contain $\mathrm{T}$ lymphocytes that are cytotoxic for cells infected by cytomegalovirus. The increased numbers of $\mathrm{OKT}^{+}$lymphocytes observed in our patient could indicate a similar cytotoxic activity against cells infected by toxoplasma.

We have been able to show a similar increase in $\mathrm{OKT}^{+}$ and $\mathrm{OKT}^{+}$cells in BAL and a decreased T4:T8 ratio which parallels the T4:T8 ratio in peripheral blood. In blastomycosis, another intracellular parasitic infection, T4:T8 ratios are also found to be reduced. ${ }^{10}$ Our observations have shown that in acute pulmonary toxoplasmosis, an increase in $\mathrm{OKT}^{8+}$ cells in peripheral blood with a decreased OKT4:OKT8 ratio cannot be explained by a redistribution of $\mathrm{T}^{+}$cells from the blood to the lung, as is suggested in sarcoidosis. ${ }^{11}$ It remains to be seen whether or not the $\mathrm{OKT}^{+}$cells in the lung contain cytotoxic activity; if they do, they could have a beneficial effect to the host by limiting the proliferation of the cells infected by toxoplasma.

\section{References}

1 Le Tan Vinh, Barbet JP, Mace B, Rousset S, Huault. La pneumonie toxoplasmique avec généralisation. Sem Hôp Paris 1980;56:744-50.

2 Ludlam GB, Beattie CP. Pulmonary toxoplasmosis? Lancet 1963;ii:1136-8.

3 Clumeck N, Sonnet J, Taelman H, et al. Acquired immunodeficiency syndrome in African patients. $N$ Engl J Med 1984; 310:492-7.

4 Theologides A, Kennedy BJ. Clinical manifestations of toxoplasmosis in the adults. Arch Intern Med 1966;117:536-40.

5 Remington JS. Toxoplasmosis in the adult. Bull NY Acad Med 1974;50:211-27.

6 De Waele M, Thielemans C, Van Camp B. Immunoregulatory $\mathrm{T}$ cells in mononucleosis and toxoplasmosis. $N$ Engl $J$ Med 1981;305:228.

7 Luft BJ, Kansas G, Engleman EG, Remington JS. Functional and quantative alterations in $T$ lymphocyte subpopulation in acute toxoplasmosis. J Infect Dis 1984;150:761-7.

8 De Waele M, Thielemans C, Van Camp B. Characterisation of immunoregulatory $\mathrm{T}$ cells in EBV-induced infectious mononucleosis by monoclonal antibodies. $N$ Engl J Med 1981; 304:460-2.

9 Quinnan GV, Manischewitz JE, Ennis FA. Cytotoxic T lymphocyte response to murine cytomegalovirus infection. Nature 1978;273:541-3.

10 Jacobs RF, Marmer DJ, Balk RA, Bradsher RW. Lymphocyte subpopulations of blood and alveolar lavage in blastomycosis. Chest 1985;88:579-5.

11 Martin II WJ, Williams DE, Dines DE, Sanderson DR. Interstitial lung disease. Assessment by bronchoalveolar lavage. Mayo Clin Proc 1983;58:751-3. 